\title{
No age of onset data available
}

INSERM

\section{Source}

INSERM. (1999). Orphanet: an online rare disease and orphan drug data base. no age of onset data available. ORPHA:409951

No information is available in the scientific literature on the age of onset of the first clinical manifestations. 